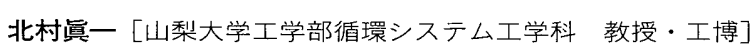

この論文はハードな環境や都市経営などに関するものでなく，企 業の経営に対する指針をテーマとした社会科学の論文と考えられま す。そして，仮設十検証というスタイルでなく，その手前の現状(現 象）十意見 (見解) といった構成です。現状については企業アンケー ト・データとヒアリングや統計などによるもので，実証性はある程 度保証されています。しかし考察（意見）は過去の経験や法則，類 似産業動向, 全国の産業動向などのデータによる実証あるいは論理 的な思考過程から導き出されたものというよりも，専門家の経験か らの論点の整理とアドバイス，言い換えれば主観的意見に近いもの です。しかしながら，地ビール企業に関する現状は経営者の視点か らは良く纏められています。主観的な意見の部分は，読者に判断を ゆだるるとしても，現状報告としては有用な情報を提供していると 考えられます。
荒川達美 [(株)まちづくり計画設計 代表取締役 $]$

本論は, 北海道において, 規制緩和により全国に波及した地ビー ルを对象に都市の活性化に及ぼす影響の特性や課題を把握してい る。北海道は，日本で初好て本格的にビール生産に着手し，「札幌」 を戴いたビールメーカーが大手の一角を成し，また本州の日本酒や 九州の焼酎の上うに地元に根ざした酒の文化が浅いなど，ビールを 受け入れやすい土㙵はある。ドイツの小都市を巡り, 歴史を感じる 直営レストランにおいて, 持参したり棚から取り出したジョッキー で割安ビールを飲み歓談している人々をよく見かけた。現在地ビー ルの值段は, 大手メーカーの 2 倍以上, さらに発泡酒がジュース類と ほほ同じ值段である。著者は, 地ビールの成功の鍵を地元の食文化 として定着することであると指摘し，そのためのアイデアが種々示 しているが, 上滑りの感が否めない, 経営者以外にも地元住民や団 体等の評価を踏まえた検討を期待したい。
川上光彦 [金沢大学工学部土木建設工学科 教授・工博]

都市計画は社会的な技術体系である。理論が制度や事業に反映さ れ，社会的な実践と時間的な鍊磨を経て蓄積されていく。その実績 について，事例を対象とする丁寧な調查と考究により，制度や事業 の評洒や問題点を明らかにすることはとても大切である。それらに もとづいて, 理論がさらに進んでいくことになる。

本研究は, 1960 年頃より開発されてきた, 札幌市の「風致資質」 の豊かな住宅地を対象として，その開発経緯などについて丁寧な調 查を行い，それが良好に維持されてきた理由などを明らかにし，今 後の計画課題を提示しているものである。特徵的な事例地区におけ る報告として価值がある。特に地方では，重要な事例等が調查され ずにいることが多いと思われる中で，高く評価できる。ただし，今 回の報告では，紙数が限定されていることから，詳細な紹介や分析 にまで至っていないのがやや残念である。今後の継続研究に期待し たい。
十代田 朗 [東京工業大学大学院情報理工学研究科情報環境学専攻 助教授・工博 $]$

質の高い開発による良好な居住環境が，長い年月を経ても維持さ れている住宅地の例は多くみられる。敷地の広さ, 緑の豊かさなど 整備された環境基盤が遺産として受け継がれていることが大きな要 因であるが，もう一つ，その地域の持つイメージの良さや文化水準 の高さが住民の居住環境に対子る高い意識や誇りを生み, さらには その意識や䛍りが環境維持に大きな役割を果たしてきたことを忘れ てはならない。別荘地から高級住宅地一と変貌を遂げた神奈川県の 湘南地方が代表例であろう。本論文は郊外住宅地開発の事例研究の 一つであるが，そのユニークさはこのソフトな効用に着眼している 点にある。結語 3) は宮の森住宅地がこの好例であることを示してお $\eta$, 提案 3) は住宅地のみならず都市環境整備手法への重要な示唆を 含んでいる。今後の研究としては, イメージ形成, 文化浸透, 住民 意識の向上の過程をより詳細に分析することが期待されよう。

\title{
防災まちづくりのための防災性評価システムの開発 一延焼危険と消防活動困難性に着目してー
}

加藤孝明, ヤルコンユスフ, 程 洪, 矢野 聡, 小出 治 227

\section{吉川 仁 [(株)防災アンド都市づくり計画室 $]$}

、発展性が期待できる有用な研究

地区レベルの市街地整備の過程にシミュレーション技術を導入 し，行政・住民・専門家に現況評価・対策効果を示すことで合理的 な意志決定が可能となる。今後，本論文の考え方を道路・Uろばな ど様々な防災まちづくりに展開することで効果的なまちづくり技術 が生み出されよう。

・防災基準のパラダイム転換への萌芽

防災研究の陷穷の一つに，一定の基準を設定しそれを達成できる か否かで評価してきたことがある。基準自体も様々な前提をもとに 設定されたこと，実際の環境改善では基準に近づくことにも意味が あることを考えると, 現状からどの程度改善されるか示すことは意 味が大きい。

-操作性・実感しやすい表現へ

研究の先には，行政職員や地域住民が利用できる防災まちづくり シミュレーターの開発が期待される。それに応じて表現のあり方， 簡便な操作性，受け取られ方等ソフトに関する研究が課題となる。
系井川栄一 [筑波大学社会工学系 教授. 工博] 本研究は，防災まちづくりにおける地区レベルの防災性を評価す るため，各地で整備が進むディジタル地理情報を活用した防災性評 価システムを構築し，ケーススタディーを通じて即地的評価の可能 性と実用性の検討を行ったものである。著者も指摘するように，具 体の市街地整備によりどのような防災性の向上があるかについて, 地区の木造率や建ぺい率などの集計指標を用いて一般論で語るには 限界があるのは明らかである。整備の対象とする具体の市街地の改 善案に対して即地的な防災性評価を行いこれをわかりやすく示すこ とが，これからの防災まちづくりを進める上で必要不可欠であり， 筆者らの研究が重要な課題であることは諭を待たない。今回の報告 では, 市街地の改善が地区内の各場所の防災性を個別に評価するこ とができる可能性を示しているにとどまるが, 今後, 評価手法の精 緻化, 計算方法の改善, 評価結果の分かりやすい提示方法等, 更な る検討を期待したい。 